\title{
Position of the Ulayat Rights in the Law and Government Policy After the Regional Autonomy in Singingi Region, Riau Province, Indonesia
}

\author{
Mhd Halkis \\ Strategy Faculty, Universitas Pertahanan, Bogor Indonesia \\ Fauzul Amri \\ Universitas Pajajaran (Unpad), Jawa Barat, Indonesia
}

\begin{abstract}
Ulayat right is a legal term related to communal rights of a community (ethnic) regarding the land environment and based on adat, collectively and hereditary. This study analyzes government policy in using customary ulayat rights. The researchers assume that environmental responsibility is related to the basic principles of environmental management: good governance, subsidiarity, and prior appropriation. The object of research in the Singingi Indigenous Territory of Riau, Indonesia, shows differences in regulations determined by the state related to economic potential and people's perception to the land. Efforts to control mining potentials have resulted in the abolition of ulayat rights, whereas the country's potential (forest potency) permits grant permits to harvest and care for forests, and the potential for agricultural potential is limited. The study concludes that the practice of the modern state has shifted collective ownership to private ownership (Shi, 2018)(Shia, 2007), but Rantau Singingi indigenous peoples have a strategy to maintain their collective ownership as an environmental responsibility.
\end{abstract}

Keywords: types of ulayat rights, customary law, land use, environmental liablity and collective ownership DOI: $10.7176 / \mathrm{JLPG} / 83-05$

Publication date:March $31^{\text {st }} 2019$

\section{Introduction}

Postcolonial countries have shifted the use of customary forest and land use (hak ulayat) to private property. For example, Riau, a province of Indonesia, has an area of 9.45 million ha, and within 24 years from, 1982-2005 lost 3.7 million ha of forests. Before Indonesia was independent, in Riau, there were 13 royal areas recognized by the Dutch East Indies that had autonomous land use rights. One of the Kingdoms that got Korte Verklarinf as Zelbestiur van Singingi was Datuak nan Baduo. Until this time, the people still held the customary rules strictly; thus, when the Government of Indonesia granted forest concession rights and land tenure without the permission of indigenous peoples, they rejected these policies, causing a cycle of conflict. Indigenous peoples depend on the expansion of land as a source of life.(Kubitza et al 2018).

The purpose of this paper is to evaluate the government policies regarding forest land use and strategies to support the indigenous people who first mastered the resources. The object of this study is Rantau Singingi, a society that still follows strong customary law. The significance of this paper to overcome the neoliberal impacts and need to review the laws that govern society (Murphy, O’Connell, \& O'Hógartaigh, 2013). In line with the United Nations Declaration on the Rights of Indigenous Peoples (2007), "recognizing indigenous peoples have suffered from the history of injustice as a result of, among other things, the colonization and deprivation of their lands, territories and resources, thus preventing them from using, in particular, their right to development in accordance with their needs and interests."

Natural resources management to create a satisfactory level of environmental quality should involve all levels of government, territorial organizations, local communities, and nongovernmental originations (Shi et al., 2018). Because developing cooperation with indigenous peoples can be difficult, given the various roles of technical experts in the organization and the baseline of political policy, providing scientific knowledge in plain language in the decision-making process to the various natural resource stakeholders through dialogue is important (Day, 1987). The failure of the government to understand and place the positios rat rights proportionately regarding the extraction of natural resources is contrary to articles 6 and 7 of ] invention No. 169. In international law, indigenous peoples have property rights to land and natural resources associated with their customary land according to their tenure system. These property rights include collective ownership of their land and withdrawing all the protections attached to the property in general (Anaya, 2012).

Legal principles of natural resource management;

a. Good governance principle. The aspects of this principle include respect for the rights and obligations of the parties, building integrity, and a foundation built on the idea that transparency is a positive part of governance. The UNDP (1997) describes good governance: the political, economic, and administrative authorities managing 
the nation's problems, resources, and public problems are conducted effectively and efficiently and respond to community needs. One or another government, community group, or company may have differing understandings of good governance, but at its core, the good governance principle represents fairness, accountability, responsibility, transparency, independence, and discipline(Hey, 2017).

b. Subsidiarity principle. This principle expects decisions on the development of natural resource management to be provided to the lowest level of government. The principle of subsidiarity emphasizes, rather than resolves, conflicts of interest between jurisdictions. The extent of the conflict of interest depends on the overflow and differences in preferences for public spending. Decisions on spending are determined by negotiations among local representatives at the center of the legislature. If no agreement is reached, the policy is determined noncooperatively by the local government (Giuranno, 2010). The quality of life and the settlements are affected by environmental conditions (Salleh, 2008). The paradox of sustainable development essentially combines environmental and human issues that move from general sentiment to specific contexts (Robinson, 2008).

c. Prior appropriation principle. Also known as "first in time, first in right, or use principle," the prior appropriation principle is the most violated in its application. In Latin, this principle is commonly found in qui prior est tempore, potior est in jure. Because the implementation of these development projects have considered the rights of the community as customary rights that cannot be undone by legal rights. Roscoe Martin gives a lucid account of some of these advantages:

"Among these, the principle of full utilization of the water resources deserves to be ranked first. Second, the appropriation system permits the use of water where needed without tying use to riparian ownership. Third, It restricts the appropriator to beneficial use, both as to purpose and as to amount and makes possible the reappropriation of excess amounts not beneficially used. Fourth, the amount, purposes and place of use of appropriated water are definitely indicated, and this adds an element or certainty which is unknown under the riparian system. Fifth, management of water resources by the courts through individual case rulings gives way under appropriation to management by a full-time administrative agency staffed by experts"(Gopalakrishnan, 1973)

The law had its ups and downs and the boundaries were limitless. Law is rarely taught to the general public. (Engel, 2004). After the independence of Indonesia, the Dutch East Indies colonial law was replaced by Indonesian Law. The era of Seokarno's and Soeharto's leadership had disappeared and was replaced by the reform era by promoting regional autonomy and local governments as policymakers.

The era of regional autonomy has built new hope for all levels of Indonesian society in the region, including indigenous peoples. Notably, the efforts and programs of the era of regional autonomy have not necessarily been implemented, because the operating companies have not expired. Land ownership conflicts between communities and companies indicate the absence of legal certainty in the field of land tenure, especially in the occupation of indigenous peoples' rights. Therefore, it is necessary to determine how far the power of customary law can defend itself in the law in the context of a continually changing regime.

\section{The Concept of Ulayat Rights}

Bakker indicated that ulayat right is a legal term that links communal rights of a community (ethnic) to the land and is based on the adat (custom or tradition) of that community (Bakker, 2008). C.S. T. Kansil and Christine S.T. Kansil (2001) distinguished the notion of customary and customary rights. The ulayat right is the right of law community/village associations to use/manage the lands around their residence/village for the benefit of the legal community or to outsiders willing to work on the land by giving some of the proceeds to the community. By contrast, Customary Law: "or adatrecht (Bld) means van Vollenhoven, Snouck Hurgronje, and Ter Haar initially to term a law comprising the people's law upon the will of their ancestors." (See Dijk, 1971). The current issue of Indonesian Adat Law studies shows a very distressing and lagging state when compared to other legal studies such as Western Law. This situation indicates how Indonesian Adat Law will be left behind and will likely be alienated from the academic community in the future (Syamsudin, 2017)

Lawrence Friedman $(1986,1969)$ posited that every society has a legal system, but not necessarily because this topic is still debated and uncertain. The question of the definition of and what the limits and answers of community law are depends on how the observer chooses to define "law" and "legal system," and for what purpose. Dozens of intellectuals have struggled with legal concepts. Obviously, there is no legal purpose or limitation, or a clear, physical limit, because the viewer's perspective also determines the legal system's definition of having it. If simplified, the legal system has three components: legal substance, legal structure, and legal culture.

Tamanaha (2006) criticized the legal pluralist view, which tends to contradict state law and people's law. According to Erhrlich, there are three aspects of the concept of law that always work: "law outside the law," "law without the state," and "lawless orders." This retrospective shows the law is basically not interested to defend the rights of such ethnic or autonomous communities. (Nelken, 2008). Legal pluralism is the coexistence of law in society, juridical legal pluralism is a state recognition of customary law, and the actor is subject to more than one 
rule of law (Griffiths, 2015). Efforts to advance traditional societies through the revitalized ethos of legal pluralism fulfill the compatibility of pluralism and liberalism. The problem, whether the liberal system of democracy can accommodate the demands of these indigenous peoples. Such an analysis revolves around the imagination of nationalism toward democratic pluralism, leading to a discourse on intergovernmental relations that affirms the legitimacy and dignity of government toward sovereign tribal groups within the territory of a country. (Duthu, 2013,43-44).

Thus, the ulayat right is considered by lawyers wanting to distinguish between private law (individual, family) and public (general) law regulated by a law for a region/neighborhood (ulayat comes from MelayuMinangkabau, a language). Because of territorial rights, it is relevant to link this right to environmental law. Laws that govern society and save the environment include controlling the negative effects in the community from the expansion of neocapitalism. Environmental rights resemble social rights, that is, customary rights are mixed with the rights of indigenous peoples but are inadequate to be the basic principle because they are different. Hence, people consider the environmental principle as a fundamental right (Hayward, 2005,65). Thus, the framework of understanding the issue of customary rights in the context of the state can be described as follows (Figure 1).

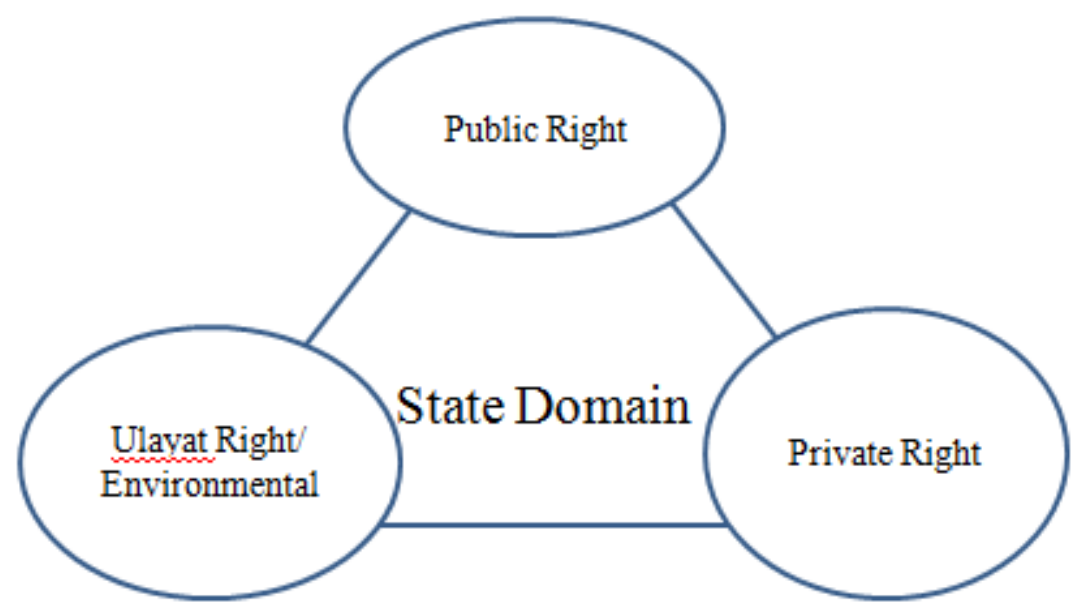

Figure 1. Position of ulayat rights in state domains as sole actor in maintaining the coexistence of law and legal life on the regulation of fair rights.

\section{Methodology}

To understand the conflicting parties, especially the government with the indigenous peoples, researchers used an ethnography method based on the book written by Paloma Gay y Blasco and Huon Wardle (2007). Attempts to find ethics and emic values are the solution to the problem. The basic problem in this ethnographic investigation is that understanding overlaps with what we understand. Differences from intrinsic and extrinsic points mark the distinction between the emic and ethical perspectives. The emic analysis describes certain cultural features of the group. The ethical perspective has been used to observe and report behavior from people's points of view regarding a cultural group. Ethical analysis implements universal features to discuss the cultural practices observed (Hoare, 2012)

In this study, the control of land is understood between the central government, local government, and indigenous peoples. Ethnographies are widely adopted by sociologists of anthropological thinking. The other's understanding of reality overlaps with what we understand. Through ethnography, it is possible to place limits on our ability to assimilate certain types of assumptions. Simply said, ethnographic methods are prepared to manage "disorganized" issues across sociocultural lines. Academically stepping beyond the universal assumption of the parameters of our knowledge is necessary.

Ethnographic applications in this study were undertaken by the researchers. The following steps were conducted. First, a review of the literature was conducted on land conflicts controlled by the business world related to communal rights. Based on selected events, the researchers chose one locus that allows for a description of the phenomenon of the ulayat rights conflict in general the Rantau Singingi Kuantan Singingi district of Riau, Indonesia. Second, the researchers learned the regulations from the constitutions and laws made by the government. Third, the researchers learned the concepts that govern the community regarding ulayat. Fourth, the researchers interpreted and constructed the data into an integral concept of government, society, and business world. 


\section{Singingi Communities Perception of Ulayat Rights}

An interview with Datuak nan Baduo, as the king of the sovereign authorities for indigenous peoples, and community leaders in Rantau Singingi was the first source to find the emic value in the culture of the society. Next, the view was discussed with the experts. The ulayat right is a privilege over the control of the forest land, along with the results received for generations, since this population came to Indonesia. The concentration of the settlement is determined by where they obtain their resources to sustain their lives, for example, the river and forest. When their source of life depends on nature, then the settlement is nomadic. This view of life and the environment determines the concept of the ulayat right. After receiving inputs from various sources and making direct observations, we observe several categories of the ulayat rights concept in Rantau Singing;

4.1. Antau, antau, or rantau, means the Singingi region, or region from upstream of the Lembu River in Logas Village and downstream of the Singingi River in Tanjung Pauh Village. Both points indicate the limit of power possessed by Datuak nan Baduo. During the Government of the Netherlands East Indies, if there were efforts related to the utilization of natural resources in that location, Datuak nan Baduo received a tribute of $10 \%$ of the proceeds. But, since the Indonesian government's award no longer exists, the era of regional autonomy has been submitted by the government to paper and plantation companies. Now, Datuak nan Baduo neither has a clear position nor authority, except for traditional ceremonial events.

4.2. Concang Latiah means a piece of wooden child in the forest as a sign. This traditional concept delineates that land tenure is granted by Datuk Nan Baduo to the tribal kings and marked by the borders of rivers, hills, or large woods, following their inheritance. Tribal rights recognize Raja Rantau Singingi against King Tribe or kaum; thus, Concang Latiah is also called hak ulayat Tribe. So, if we observe the category of ulayat rights according to Sjahmunir, the Concat Latiah belongs to the ulayat king and tribal ulayat categories.

4.3. Tanah Kojan means that the Kingdom Land is centered at the Muara Lembu. An outlet with the lower boundary of Kebun Kado Village and upper boundary of Pulau Padang Village. (In Adat Singingi, Said: Kapalo koto Pulau Padang, ikuagh koto Kobun Lado). These three villages are the core villages where Datua nan Baduo and Datuak nan Batujuah are holders of the tribes' Ulayat. Structure, division authority, and power are well regulated; thus, they can work synergistically. The community greatly respects the origin of the descendants' position and does not distinguish it from the village among the three villages, as judged in one city.

4.4 Kopuang means intact forests abandoned by the community, and the areas around the forest are freely controlled by private citizens and indigenous sub-community groups (tribes). Kopuang occurs because a custom agreement forbids the community to be taken personally, usually for religious purposes. For example, Rimba Kepungan Mesjid in the village of Kebun Lado.

4.5. Lubuak. or Lubuk, means the deepest part of the river rod and is called the bottom. Lubuk, when close to the village, has been prohibited. Fish may be caught with traditional equipment to ensure the maintenance of the species. Lubuk Larangan in Pangkalan Indarung Village, for example, functions as a fish source for residents and has also become tourist destination. Every year, after the fasting month, a fishing event is held.

4.6. Kapalo Ladang means control of land by a tribal group, family, or person to make ends meet based on the garden or field cultivated. Previously cultivated fields became the basis of control over the forest thereafter. The people cannot make a garden in the forest if permission has not been granted from the person who created the previous garden. Hak Ulayat based on Kapalo Fields that have been planted with old plants on private property, whereas not planted old gardens belong to tribal ulayat.

4.7. Sosok means control of land by a person or a tribe for ever making a garden or at least slash-cutting for a garden-making plan to make ends meet. Ownership of the plot, when planted with old plants on private property, and if not planted with old plants remain the property of tribal ulayat.

4.8. Polak means traditionally cultivated gardens near a kampong. The land is planted with palawija crops and harvested for household consumption or sold. Polak can be passed down from generation to generation, even to a family or girls. Boys are not allowed to inherit poles acquired through offspring, unless there are no daughters.

4.9. Tanah Paumaan, or land lousing, is land on which there are permanent residential houses. The house of inheritance is inherited to the youngest daughter. Boys do not commonly inherit the Land of Housing, even if there are no girls, it is usually sold and shared by fellow men. 
4.10. Pusako Tuo, or the Old Heritage = Old Treasury, means a sign of greatness passed on offspring by a maternal line. Usually shaped like a kris, knife, or spear. Considered similar to Tombak Majapahit Pamor Tunggak Semi.

The visible stretch of rural areas has been divided and regulated according to tribal laws, and was developed after Indonesia became independent of the central government in the context of economic development in a centralized manner. The description of ulayat rights overlaps with the central government's policy for the transmigration from Java Island and the Industrial Plantation Forest Development/Hutan Tanaman Industri (HTI) materials to make paper powder. In the internal community, there is overlapping issues of private rights and communal rights. The extent of such ultimate rights can be described as follows (Figure 2).

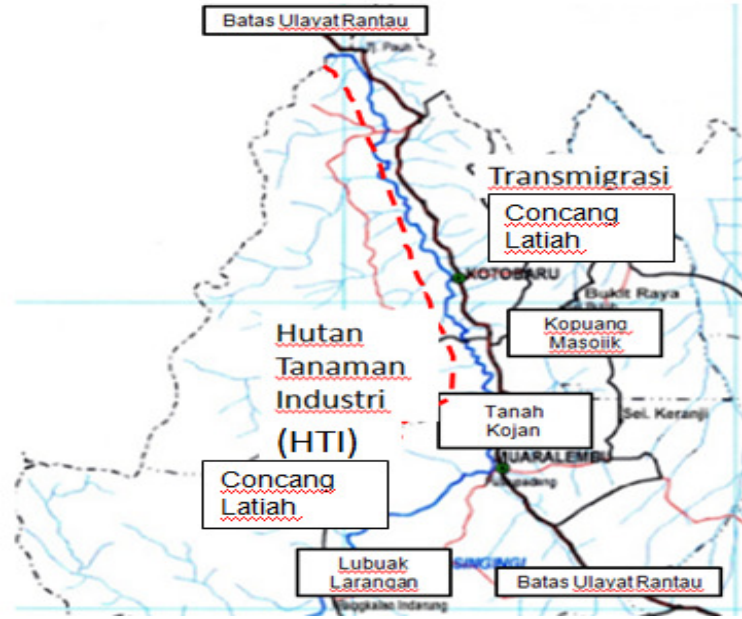

$\mathrm{a}$

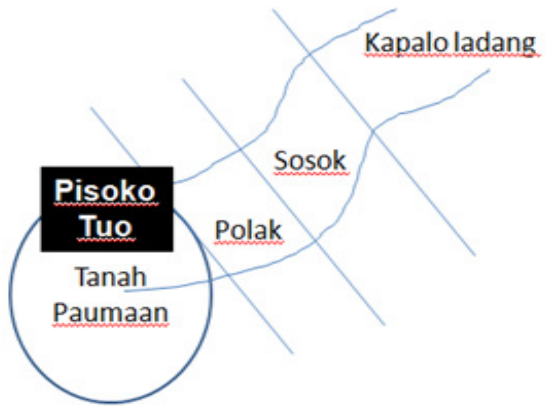

b

Figure 2. (a) Singingi ulayat right Zone, overlapping with the Central Government Policy of the Industrial Timber Plantation (HTI) and Transmigration Program. (b) Right category of ulayat leads to private property.

\section{Discussion of Ulayat Rights in Positive Law and Sociology of Law}

Article 33 paragraph (3) of the 1945 Constitution reads; "The earth and the water and the natural wealth contained therein are controlled by the state and used for the greatest prosperity of the people." The main problem for the state of Indonesia is how to ensure the community prospers by utilizing all potential resources, especially natural resources.

In Law no. 5 of 1960, based on the Basic Regulations of Agrarian Principles, there are several articles of arkais, among others: "In the consideration of the agrarian law it is explained that national agrarian law is based on customary law on land, simple and guaranteed legal certainty for all Indonesian people." Then, Article 15 reads, "Maintaining the land, including increasing its fertility and keeping its damage is every obligation person, legal entity or institution having legal relationship with the land, with due regard to the weak economic party." Then, chapter 2 states, "Earth, water and space, including the riches of nature contained therein at the highest level controlled by the state." Notable is a statement that agrarian law is based on customary law, but Article 2 regulates the use of land; thus, there has been exploitation of indigenous peoples by the state. Thus, the exclusion of customary rights occurs after customary rights are taken as the basis of rights for the state.

Act. No. 18 of 2004 concerning plantations shall contain customary rights or similar community rights as Article 9 paragraph (2), "In the case that the land required is customary community ulayat land which, in reality still exists, precedes the granting of rights as meant in paragraph (1), the applicant shall conduct consultation with the customary law community of the ulayat right holder and the citizen holder of the land rights in question, to gain agreement on the surrender of the land, and the rewards."

Act. No. 41 of 1999 concerning Forestry includes the law that contains the existence of the ulayat right in full, which was born before the amendment of UUD 45 stage II sahkan. In Forestry Law Article 67, paragraph (1) reads, "The customary law community insofar as it is in fact still exist and acknowledged its existence is entitled: a. to collect forest products to fulfill the daily needs of the indigenous peoples concerned; $b$. undertake forest management activities under applicable customary law and is not contrary to law: and c. get empowerment to improve their welfare."

The Dutch East Indies colonial era imposed the Indische Mijn Wet in 1899 to regulate mining issues. This law delegates the authority of the Dutch East Indies government to grant mining concessions to private parties. 
This authority is contrary to the kingdoms that still existed at the time, but benefitted the recognized kingdom. The joint management agreement in the form of concession contractor is required to pay vast rech for each hettar of concession area granted, and a royalty of $4 \%$ of gross production. In exercising its concession rights, the contractor has full management authority, and the resulting oil belongs to its owner.

Consequently, the government does not have the access and ability to determine the selling price and availability of oil in the country for whom the oil was produced. The deprivation of community rights in the form of land and relocation of land to infertile land negatively effects the livelihoods of rural households around the mine (Mtero, 2017). It is important for the government to understand local customary norms and obtain approval from local communities before the permits are granted by the government to third parties (Debrah, 2018)

Early independent Indonesia Indische Mijn Wet became the basis for the development of the Petroleum Act Act no. 44 Prp. Year 1960 About Oil and Gas Mining. The law does not discuss the status of ulayat rights. Similar is the Law of the Republic of Indonesia Number 4 Year 2009 About Mineral and Coal Mining. This law differentiates the People's Mining Area and the Mining Business License. Notably, the People Mining Permit/Izin Pertambangan Rakyat may only be granted to individuals and at most 1 (one) ha; In this law, no permits are granted to indigenous peoples other than community groups of up to 10 people.

Act.No.23 of 1997 on Environmental Management approached the issue of the existence of the ulayat right only Article 9 paragraph (1), "The Government implements national policy on environmental management and spatial planning while maintaining religious values, customs, and values that live in society." The Law on the Environment does not specify regarding the ulayat right expressly, but in Article 37, this law provides an opportunity for the community and environmental organizations to file a lawsuit; chapter 37 indicates that the public is entitled to file a representative lawsuit to the court and/or report to law enforcement on a range of environmental problems adversely affecting the livelihood of the community. In this Law, the strict liability issue and Article 88 Law No. 32 Year 2009 on Environmental Protection and Management has been regulated.

Discovering the ulayat right of rights in material law and proving them in formal law or civil procedure law, even in Western civil law, for certain criteria, is difficult. Sunguhpun also needs to understand the ulayat right when managing the law of Western civil events in court. The first issue faced in fighting for ulayat rights through civil procedure law in court is "verification of rights," that is, the ulayat rights struggle does not adhere to the prevailing law or regulation. This proof is important because it presents what has been observed according to the law and is sufficient to provide assurance to the judge regarding an event or legal relationship. As described in 163 HIR-283 R.Bg., whoever says he has a right or mentions an event to affirm his right or deny the rights of others must prove the existence of that right or event. Referring to this article, indigenous leaders will encounter difficulties, especially regarding the verification of rights as regulated in Article 164 HIR-284 R.Bg., which outlines five types of evidence: letter proof, witness evidence, suspicion, confession, and oath.

The law sociology approach according to Lawrence Friedman cannot be imposed on society solely as the object of law. Damage occurs to the part of government policy in the long-term merupkan integration of the problem in a chain. Basically, the precautionary principle of determining environmental liabilities is more likely. Although ultimately about responsibility, the often-stressed effect is the inversion of burden of proof. If the public is guilty until they can be proven innocent, the principle of caution may also affect the balance between strict and error-based responsibility (Belt and Gremmen, 2002).

One of the simples concept of legal pluralism was found by Leopold Pospisil (1967) on the level of law. Pospisil mentioned the social structure and described it as something that is khirarkis and fragmented. Pospisil stated that no single society has a single legal system, and the legal system in the form of khirarki reflects the level of inclusiveness of various small groups of society. The descriptive theory (M.G.Smith, 1960) was formulated in a political perspective, which subsequently gave birth to the concept of "corporation" as the main institution of social structure and main vehicle of political activity associated with the public. Another notable concept of legal pluralism is Ehlrich's Theory (Partridge, 2006) on "Living Law." Ehlrich distinguished between rules that make decisions with rules that behave. The positive law adopted by the state is only a rule in making decisions and views law as a pure science not influenced by practices in government. The development of positive law supports the principles of law.

The hierarchy of law in the ulayat right is also reflected the strength of the law. The Ulayat Antau and Kojan Land rights are so wide that they are no longer visible. Since the autonomy of the Rantau Singingi Region, which was once one, has now become two sub-districts; thus, the coordination line of adat leaders is also almost disconnected. Likewise, with the Tanah Kojan of three villages unified, the villages are self-reliant in terms of government, programs, and funding. The ulayat right held by the community is an old library (Pusaka Tuo) and the land of settlement (land of paumaan). Hiraki hak ulayat Rantau Singingi can be described as follows (Picture $3)$. 


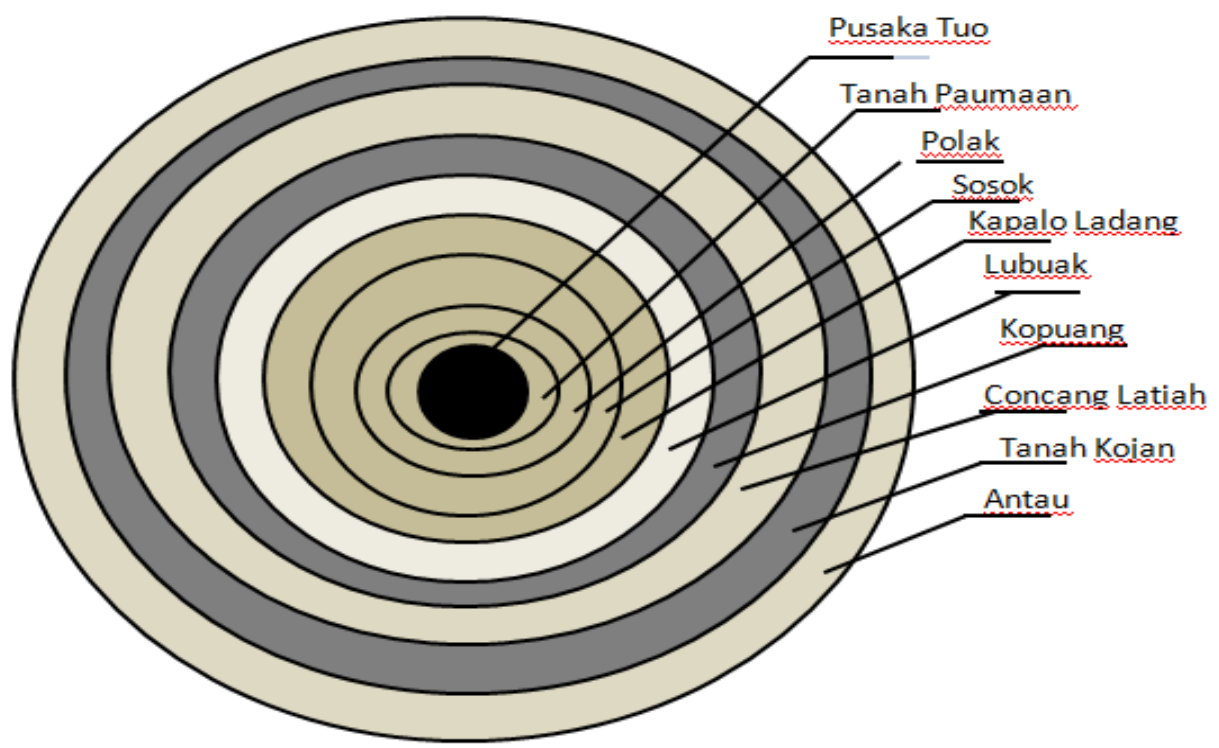

Picture 3 : Circle of Positions of ulayat rights.

\section{Conclusions}

The legal reality is not single. There are at least three legal "rights," and these are maintained in a balanced manner: public rights, private rights, and territorial rights (ulayat). There is no more dominant state partiality, the government regulates it. The law retains its balance, and the law has its limits (Antony Allot, 1981, David McIlroy, 2015), including collective ownership status. The dominance is observed in the competition and transition of urban society with the village community (Gant, 2011). State forest and land concession programs for entrepreneurs implemented in the Soeharto government have succeeded in stopping communities from settlements and shifting cultivation. Notably, these dismissals and arrangements have not accompanied by settlement and living environment arrangements; thus, the exploitation of environmental resources is uncontrolled. The era of regional autonomy is an opportunity for indigenous peoples to organize ulayat rights (McWilliam, 2006), but that occurs as if there is a transfer of environmental liability from the central government to the local government, whereas demanded justice is not a formality but a moral obligation that has autonomous rights (Hiskes, 2008,11) When the legal system of legal products issued by the local government is not much help to regulate forest and land governance, then the legal duty in environmental liabilities becomes uncertain. If customary rights are placed within the framework of environmental law, indigenous peoples have a class action in requesting environmental responsibility from the government. Governance is bound to occur, but the view of ulayat rights must be optimistic, in which the wealth of society is available for commodities and mini-public needs; then, the government ensures an adequate future (Tilton et al., 2018). The ulayat right can be considered a rural institution that is difficult to adapt to the development and interests of capitalists.

Development policy separates community development and development, and the community is left to selfmanage. In essence, development in the community areas that disregarded the indigenous peoples has violated three principles of good environmental management: good governance, the subsidiarity principle, and the prior appropriation principle. Massive environmental damage along with an increase in the number of environmental crimes has been observed. The recognition of a living community law, if acknowledged in part by the law of the state, will be difficult when attributing environmental responsibility. Notably, the community feels possessed but cannot be their own master; thus, the disadvantaged society can neither explore wealth nor bear the long-term environmental effects. The state mining sector seems to consider its effect on indigenous peoples in a manner where their ulayat rights are not recognized. For that type of development, it is important to include the government but not rule out the community (Vining \& Richards, 2016).

\section{Acknowledgements}

Research is independent academics and not interested in the results of research. I would like to thank the Kuantan Singingi District Government for providing financial and administrative support. To Professor Dr. Ade Saptomo SH and Sukanda Husein, S.H., LLM from Andalas University who direct the writing of this paper. To Datuak nan Baduo and Datuak nan Batujuah have provided sufficient input on the implementation of this research. 
References

Anaya, James, 2005, Indigenous Peoples' Participatory Rights In Relation To Decisions About Natural Resource Extraction: The More Fundamental Issue Of What Rights Indigenous Peoples Have In Lands And Resources, Arizona Journal of International \& Comparative Law Vol 22, No. 1

Badan Pusat Statistik, 2012, Statistik Perusahaan Hak Pengusahaan Hutan, Statistics of Forest Consession Estate, Jakarta.

Bakker, Laurens, 2008, “Can we get hak ulayat?" Land and community in Pasir and Nunukan, The research is part of the Indonesian-Dutch INDIRA project and of the Indonesian-Dutch Tropenbos Gunung Lumut Biodiversity research project 2004-2006, Center for Southeast Asia Studies, Permalink https://escholarship.org/uc/item/5pj3z2jr

Belt, Henk van den, Bart Gremmen, 2002, Between Precautionary Principle and "Sound Science": Distributing the Burdens of Proof, Journal of Agricultural and Environmental Ethics 15(1):103-122

Day, Diana Gwendoline, 1987, Australian natural resources policy, Water and land, Resources Policy, Volume 13, Issue 3, pp. 228-246

Davidson, Julie, Michael Lockwood, Allan Curtis ,Elaine Stratford, Rod Griffith, 2006, Governance Principles For Regional Natural Resource Management, December Report No. 1 of The Project Pathways to good practice in regional NRM Governance

Debrah, Akua Asamoah, Hudson Mtegha, Frederick Cawood, 2018, Social licence to operate and the granting of mineral rights in sub-Saharan Africa: Exploring tensions between communities, governments and multinational mining companies, Resources Policy, Volume 56,

Duthu, N. Bruce, Shadow Nations, Tribal Sovereignty and the Limits of Legal Pluralism, Oxford University Press, 198 Madison Avenue, New York, NY 10016

Engel, Christoph, 2008, Learning the Law, Journal of Institutional Economics 4(03):275-297, DOI: $10.2139 /$ ssrn.539982

Friedman, Lawrence M. ,1986, The Law and Society Movement, Stanford Law Review, Vol. 38, No. 3 1969, The Legal System : A Social Science Perspective, Russel Sage Foundation, New York

Friedrich, Carl Joachim, 2004, The Philosophy of Law in Historical Perspevtive (terj.Filsafat Hukum Perspektif Historis oleh Raisul Muttaqin), Nuansa dan Nusamedia, Jakarta

Gant, Robert L., Guy M. Robinson, Shahab Fazal, (2011) Land-use change in the 'edgelands': Policies and pressures in London's rural-urban fringe, Land Use Policy 28, DOI:10.1016/j.landusepol.2010.06.007

Griffiths, John 2015, Legal Pluralism, International Encyclopedia of the Social \& Behavioral Sciences (Second Edition), Pages 757-761

Giuranno,Michele G., 2010, Pooling sovereignty under the subsidiary principle, European Journal of Political Economy 26 125-136

Gopalakrishnan, Chennat, The Doctrine of Prior Appropriation and Its Impact on Water Development A Critical Survey, 1973, The American Journal of Economics and Sociology, Vol. 32, No. 1 (Jan., 1973), pp. 61-72, https://doi.org/10.1111/j.1536-7150.1973.tb02180.x

Hayward, Tim,(2005) Constitutional Environmental Rights, Oxford University Press Inc., New York

Hey, Robert Bruce ,2017, What Are the Principles of Good Governance? Chapter 7 - Performance Management for the Oil, Gas, and Process Industries A Systems Approach, Pages 91-105

Hiskes, Richard P.(2009), The Human Right to a Green Future environmental rights and intergenerational justice, Cambridge University Press, The Edinburgh Building, Cambridge CB2 8RU, UK Published in the United States of America by Cambridge University Press, New York

Higgins,Karen L. Striking a balance between unbounded economic growth and sustainability requires a new mindset, 2013

Hoare, Karen J. Stephen Buetow, Jane Mills James, 2012, Using an emic and etic ethnographic technique in a grounded theory study of information use by practice nurses in New Zealand, Journal of Research in Nursing 18(8), , DOI: 10.1177/1744987111434190

Hutchinson, Emma, Klaas van 't Veld, 2005, Extended liability for environmental accidents: what you see is what you get, Journal of Environmental Economics and Management 49 157-173

John D. Brewer, 2000, Ethnography, Open University Press, Buckingham - Philadelphia Celtic Court 22 Ballmoor Buckingham

Kansir, C.S.T. dan Critine S.T. Kansil, 2001,Kamus Istilah Aneka Hukum, Pustaka Sinar harapan, Jakarta

Kubitzaa, Christoph, Vijesh V. Krishnaa, Kira Urban, Zulkifli Alamsyah, Matin Qaim, 2018, Land Property Rights, Agricultural Intensification, and Deforestation in Indonesia, Ecological Economics 147, 312-321 DOI: 10.1016/j.ecolecon.2018.01.021

McWilliam, Andrew, 2006, Historical Reflections on Customary Land Rights in Indonesia, The Asia Pacific Journal of Anthropology, 7:1, 45-64, DOI: 10.1080/14442210600551859 
Mtero, Farai, 2017, Rural livelihoods, large-scale mining and agrarian change in Mapela, Pospisil, Leopold, 1967, Legal Levels and Multiplicity of Legal Systems in Human Societies, Journal of Conflict ResolutionVolume: 11 issue: 1, page(s): 2-26, Issue published: March 1, DOI:10.1177/002200276701100102

Murphy, Tim, 2013, Vincent O'Connell, CiaránÓ hÓgartaigh, Discourses surrounding the evolution of the IASB/FASB Conceptual Framework: What they reveal about the "living law" of accounting, Accounting, Organizations and Society, Volume 38, Issue 1, Pages 72-91

Nelken, David, 2008, Eugen Ehrlich, Living Law,and Plural Legalities, Theoretical Inquiries in Law 9.2

Partridge P.H., 1961, Ehrlich's sociology of law, Australasian Journal of Philosophy Volume 39, - Issue 3 Pages 201-222, Published online: 15 Sep 2006, DOI:10.1080/00048406112341181

Paloma Gay y Blasco and Huon Wardle, 2007, How to Read Ethnography, Routledge 2 Park Square, Milton Park, Abingdon, Oxon OX14 4RN Simultaneously published in the USA and Canada by Routledge 270 Madison Ave, New York, NY 10016

Pellizzoni, Luigi, 2004, Responsibility and Environmental Governance, Environmental Politics, Volume 13, Issue 3

Robinson, Guy M. , 2008, Sustainable Rural Systems, Sustainable Agriculture And Rural Communities, Ashgate,Hampshire Gu11 3hr, England,

Salleh, Abdul Ghani, 2008, Neighbourhood factors in private low-cost housing in Malaysia, Habitat International $32,485-493$

Schorr, David B, 2005, Appropriation as Agrarianism: Distributive Justice in the Creation of Property Rights, Ecology Law Quarterly, Volume 32 Issue 1 Article 1

Shia, Linda, Zachary Lambb , Xi (Colleen) Qiub, Hongru Caib, Lawrence Vale, 2007. Promises and perils of collective land tenure in promoting urban resilience: Learning from China's urban villages, Habitat International Volume 31, Issue 2, , Pages 167-176

Smith, M.G., 1960, "Social and Cultural Pluralism,"Social and Cultural Pluralism in the Caribbean., Vera Rubin, Annals of the New York Academy of Sciences, 83, art 5,763-777

Syamsudin, M., Reorientation of Approaches in Indonesian Customary Law Studies, 2017, Journal of Indonesian Adat Law (JIAL) ISSN (Cetak) : 2581 - 0952, ISSN (Online) : 2581 - 2092 www. jial.apha.or.id Volume 1 Nomor 1, Hlm. 1-29

Tamanaha, Brian Z., 2006, Law as a Means to an End Threat to the Rule of Law, ambridge University Press The Edinburgh Building, Cambridge cb2 2ru, UK

Tiltona, John E., Phillip C.F. Crowsonc , John H. DeYoung Jr.d, Roderick G. Eggerta , Magnus Ericssone , Juan Ignacio Guzmánb, David Humphreysf, Gustavo Lagosb, Philip Maxwellg, Marian Radetzkie, Donald A. Singerh, Friedrich-W. Wellmeri,j, 2018, Public policy and future mineral supplies, Resources Policy 57, $55-6$

United Nation, Resolution adopted by the General Assembly [without reference to a Main Committee (A/61/L.67 and Add.1)] 61/295. United Nations Declaration on the Rights of Indigenous Peoples

Vining, Aidan R., John Richards, 2016, Indigenous economic development in Canada: Confronting principalagent and principal-principal problems to reduce resource rent dissipation, Resources Policy, Volume 49, Pages 358-367, DOI:10.1016/j.resourpol.2016.07.006 